\title{
METHODOLOGY
}

\section{A LEUKOCYTE CRYOPRESERVATION TECHNIQUE FOR CYTOGENETIC STUDIES}

\author{
José Maurício Barbanti Duarte ${ }^{1}$, Mariney Flávia Pereira Di Tano Ramalho ${ }^{2}$, Vera Fernanda \\ Hossepian de Lima ${ }^{2}$ and Wilham Jorge 3
}

\begin{abstract}
Several culture, cryopreservation, freezing and thawing methods were tested to develop an efficient technique for storing cervid and ovine leukocytes. The best results were obtained with McCoy or Vega y Martinez (VYM) solution with dimethyl sulfoxide (DMSO), horse serum and polyvinylpyrrolidone (PVP) as cryopreservatives. The best protocol for freezing was $4^{\circ} \mathrm{C}$ for $30 \mathrm{~min}$ followed by $15 \mathrm{~min}$ in liquid nitrogen vapor. To thaw, the still frozen material was placed onto cultivation medium for propagation.
\end{abstract}

\section{INTRODUCTION}

Cellular cryopreservation is an important mechanism to store genetic material. During the freezing process, cells suffer injuries that most times result in death. According to Grout et al. (1990), the main problems during cryopreservation are cellular exposure to low temperatures, mechanical and physical effects of the ice crystals and property alterations of the extracellular solutions, which consequently alter the intracellular environment. Mazur (1970) indicated that damage caused by solution effects could be controlled by increasing the freezing speed, thereby decreasing the time between freezing the extra and intra-cellular solutions. On the other hand, the intracellular freezing effect could be minimized by decreasing freezing speed, and thus suppressing crystal formation. Therefore, every cell type has an optimum freezing speed that counterbalances the extra- and intra-cellular effects.

Some cryoprotective substances have been used to minimize cellular damage occurring in liquid nitrogen storage $\left(-196^{\circ} \mathrm{C}\right)$. There are two types of cryoprotectors: those that permeate the cells, like dimethyl sulfoxide (DMSO), glycerol, sucrose, trehalose, methanol, glucose, 1.2 propanediol, proline, glycine betaine, fructose, galactose and lactose, and those cryoprotectors that do not permeate the cells, such as hydroxy ethyl starch, dextran and poly-

\footnotetext{
${ }^{1}$ Departamento de Melhoramento Genético Animal and Departamento de ${ }^{2}$ Reprodução Animal, FCAV/UNESP, 14870-000 Jaboticabal, SP, Brasil. Send correspondence to J.M.B.D., Rodovia Carlos Tonanni, km 05, Fax: +55-16-322-4275, E-mail: barbanti@fcav.unesp.br

${ }^{3}$ Departamento Biologia Geral, ICB/UFMG, Caixa Postal 486, 30161-970 Belo Horizonte, MG, Brasil.
}

vinylpyrrolidone (PVP) (Grout et al., 1990). The exact protective mechanism of these substances is still not clear (Mazur, 1970).

Speed, not just of freezing but also of thawing, possibly interferes with cell viability. Rall et al. (1980) found ice crystals formed in the cytoplasm of mouse embryos that were slowly heated. These crystals did not form during freezing. Furthermore, the critical temperature for formation of these crystals was $-65^{\circ} \mathrm{C}$. If the samples were heated slowly until $85^{\circ} \mathrm{C}$ and then heated quickly, these crystals did not form.

Protozoa (Babesia) were successfully frozen by Vega et al. (1985), using Vega y Martinez (VYM) solution with $10 \%$ PVP. After thawing, the material was washed with VYM and deposited in culture.

Nachimuthu et al. (1992) worked with baby hamster kidney (BHK), Mardin-barby bovine kidney (MDBK), chicken embryo-related (CER) and Vero cells. The BHK, MDBK and CER lineages had approximately $90 \%$ protection with DMSO (10\%), while the Vero cells were only protected by $20 \%$. Association of $5 \%$ DMSO and $5 \%$ glycerol in the freezing medium was capable of protecting $66 \%$ of the Vero cells.

Heszky et al. (1990) worked with plant cells (Puccinellia distans (L.) Parl.). They tested three cryoprotectors and five pre-nitrogen temperatures. Samples were cooled at $1^{\circ} \mathrm{C} / \mathrm{min}$ until $-10^{\circ},-20^{\circ},-30^{\circ},-40^{\circ}$ or $-50^{\circ} \mathrm{C}$, before being submerged in liquid nitrogen. The best results were obtained with $12.5 \%$ proline as a cryoprotector, at a temperature of $-30^{\circ} \mathrm{C}$, which resulted in $78 \%$ cell protection. Concentrated glycerol $(12.5 \%)$ at $-40^{\circ} \mathrm{C}$ protected $58 \%$ of the cells.

Cryopreservation protocols vary greatly with cell type. The objective of the present study was to standardize a leukocyte storage technique for use in cytogenetics, which would facilitate material collection from animals in the field.

\section{MATERIAL AND METHODS}

Ten milliliters of blood was collected in heparintreated tubes from Ovis aries or Mazama sp. (Cervidae, Mammalia). The blood was centrifuged at 1,000 rpm for $5 \mathrm{~min}$, and then maintained at $4^{\circ} \mathrm{C}$ for 15 to $30 \mathrm{~min}$ so that there would be agglutination of the leukocyte ring. The leukocyte ring was removed $( \pm 1 \mathrm{ml})$ with a Pasteur pipette and deposited in $4 \mathrm{ml}$ culture medium with the cryoprotector. The following media were tested: VYM (Vega et al., 1985), Hank's, McCoy's, Ham's F10 and heat-inactivated horse serum with 
DMSO (6 to $12 \%)$, PVP (10\%), serum and antibiotics. The cellular solutions were then stored in 0.5 -ml straws for 0,10 or $30 \mathrm{~min}$ in the refrigerator, 0 or $15 \mathrm{~min}$ in the freezer or 0 or $15 \mathrm{~min}$ in liquid nitrogen vapor ( 1 to $2 \mathrm{~cm}$ above the nitrogen level). Afterwards, the material was submerged in liquid nitrogen, where it remained for one week to six months.

Thawing was achieved by one of two procedures: immersing the straws in water at room temperature until completely thawed or opening the straw and depositing the still frozen material onto the culture medium. The objective of the latter was to dilute the potentially toxic cryoprotector before the cell initiated metabolism. The medium used was Ham's F10 with $20 \%$ heat-inactivated horse serum, $5 \%$ phytohemagglutinin, $100 \mathrm{IU} / \mathrm{ml}$ penicillin and $0.1 \mathrm{mg} / \mathrm{ml} \mathrm{strep-}$ tomycin. The cells were incubated at $37.5^{\circ} \mathrm{C}$ for $72-120 \mathrm{~h}$, and subsequently conventional cytogenetic techniques were used for blocking metaphase cells through colchicine, hypotonization, fixation and mounting on slides.

Results were evaluated by the occurrence or not of metaphase nuclei in the cultivated material. The quantity of whole nuclei on the slides was also an evaluation factor.

\section{RESULTS AND DISCUSSION}

Of the basic culture mediums tested, the best results were obtained with McCoy's and VYM. DMSO as the only cryoprotector in the freezing medium was able to protect cells from cryogenic effects, but the best result was obtained with the association of DMSO $(6.25 \%)$ and PVP (10\%). The addition of $20 \%$ heat-inactivated horse serum in the freezing medium also improved the final results.

The best freezing protocol was $4^{\circ} \mathrm{C}$ for $30 \mathrm{~min}$ followed by $15 \mathrm{~min}$ in liquid nitrogen vapor before immersion in liquid nitrogen.

The best thawing protocol was the placement of the still frozen material onto the culture medium at room temperature.

Freezing medium: $3 \mathrm{ml}$ McCoy's medium, $0.8 \mathrm{ml}$ heat-inactivated horse serum, $0.25 \mathrm{ml}$ DMSO, $400 \mathrm{mg}$ PVP, $0.4 \mathrm{mg}$ streptomycin and 400 units penicillin.

\section{Protocol:}

1. Collect blood in heparin-treated tubes

2. Centrifuge at $1,000 \mathrm{rpm}$ for $5 \mathrm{~min}$

3. Refrigerate $\left(4^{\circ} \mathrm{C}\right)$ for $30 \mathrm{~min}$

4. Deposit $1 \mathrm{ml}$ of the leukocyte ring onto $4 \mathrm{ml}$ freezing medium $\left(4^{\circ} \mathrm{C}\right)$

5. Store media with the cells in $0.5-\mathrm{ml}$ straws

6. Refrigerate for $30 \min \left(4^{\circ} \mathrm{C}\right)$

7. Leave $15 \mathrm{~min}$ in liquid nitrogen vapor $(2 \mathrm{~cm}$ above liquid level)

8. Submerge in liquid nitrogen

This technique has been used with approximately 1,000 cell cultures, with an average success rate of $20 \%$. The cultivated material had adequate growth in these samples, though the quality was inferior to that of cultures realized with fresh material. To increase the number of cells per slide, cell culture time was increased from 72 to $120 \mathrm{~h}$. According to Tanaka et al. (1979), the freezing process can cause mutations in Escherichia coli; nevertheless, the authors dissected the bacteria after freezing, and the present work did not. It is still unknown the real influence of freezing on the chromosome morphology. If any break or rearrangement in the chromosome happens, the cell would be unable to propagate in vitro. Continuing the typical cellular cycle, the normal cells will proliferate perfectly, and the ones with many chromossomic rearrangements will become unstable and will die. Some metaphases with a large number of breaks appeared in the material, but were very rare.

This technique could be used for storage of cytogenetic material for long periods of time. Furthermore, collection in the field would be facilitated. The material could then be transported to a laboratory and propagated under more aseptic conditions and with better equipment for long-term cultivation.

\section{ACKNOWLEDGMENTS}

The authors thank the technicians Paulo Antonio Tosta and João Airton Boer for help in the laboratory. Publication supported by FAPESP.

\section{RESUMO}

O presente estudo teve como objetivo desenvolver uma técnica eficiente de estocagem de leucócitos de cervídeos e ovinos para posterior cultivo e obtenção de preparações citogenéticas. Vários meios de cultura, crioprotetores e protocolos de congelação e descongelação foram utilizados. Foram obtidos os melhores resultados utilizando-se meio de cultura McCoy ou VYM, acrescidos de DMSO, soro equino e PVP como crioprotetores. O melhor protocolo de congelação foi submeter as células a 30 minutos em $4^{\circ} \mathrm{C}$ e 15 minutos em vapor de nitrogênio líquido, e para descongelação, o lançamento do material ainda congelado no meio de cultivo para propagação.

\section{REFERENCES}

Grout, B., Morris, J. and McLellan, M. (1990). Cryopreservation and the maintenance of cell lines. Trends Biotechnol. 8: 293-297.

Heszky, L.A., Jekkel, Z. and Ali, A.H. (1990). Effect of cooling rate, cryoprotectant and holding time at different transfer temperatures on the survival of cryopreserved cell suspension culture (Puccinellia distans). Plant Cell, Tissue Organ Cult. 21: 217-226.

Mazur, P. (1970). Cryobiology: The freezing of biological systems. Science, 168: 939-949.

Nachimuthu, K., Padmaraj, A. and Padmanaban, V.D. (1992). Cryopreservation of cell lines. Indian Vet. J. 69: 472-473.

Rall, W.F., Reid, D.S. and Farrant, J. (1980). Innocuous biological freezing during warming. Nature, 286: 511-514.

Tanaka, Y., Yoh, M., Takeda, Y. and Miwatani, T. (1979). Induction of mutation in Escherichia coli by freeze-drying. Appl. Environ. Microbiol. 37: 369-372.

Vega, C.A., Buening, G.M., Rodriguez, S.D., Carson, C.A. and McLaughlin, K. (1985). Cryopreservation of Babesia bigemina for in vitro cultivation. Am. J. Vet. Res. 46: 421-423.

(Received March 19, 1998) 